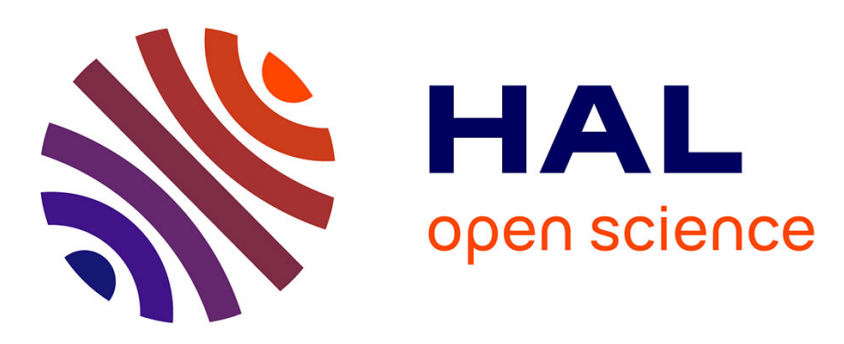

\title{
Triclinic-Cubic Phase Transition and Negative Expansion in the Actinide IV (Th, U, Np, Pu) Diphosphates
}

Gilles Wallez, Philippe E. Raison, Nicolas Dacheux, Nicolas Clavier, Denis Bykov, Laurent Delevoye, Karin Popa, Damien Bregiroux, Andrew N. Fitch, Rudy J. M. Konings

\section{To cite this version:}

Gilles Wallez, Philippe E. Raison, Nicolas Dacheux, Nicolas Clavier, Denis Bykov, et al.. TriclinicCubic Phase Transition and Negative Expansion in the Actinide IV (Th, U, Np, Pu) Diphosphates. Inorganic Chemistry, 2012, 51 (7), pp.4314-4322. 10.1021/ic300036y . hal-01492770

\section{HAL Id: hal-01492770 https://hal.sorbonne-universite.fr/hal-01492770}

Submitted on 27 Aug 2020

HAL is a multi-disciplinary open access archive for the deposit and dissemination of scientific research documents, whether they are published or not. The documents may come from teaching and research institutions in France or abroad, or from public or private research centers.
L'archive ouverte pluridisciplinaire HAL, est destinée au dépôt et à la diffusion de documents scientifiques de niveau recherche, publiés ou non, émanant des établissements d'enseignement et de recherche français ou étrangers, des laboratoires publics ou privés. 


\title{
Triclinic-Cubic Phase Transition and Negative Expansion in the Actinide IV (Th, U, Np, Pu) Diphosphates
}

\author{
Gilles Wallez, ${ }^{* \dagger}{ }^{\dagger}$ Philippe E. Raison, ${ }^{\ddagger}$ Nicolas Dacheux, ${ }^{\S}$ Nicolas Clavier, ${ }^{\S}$ Denis Bykov, \\ Laurent Delevoye, $"$ Karin Popa, ${ }^{\perp}$ Damien Bregiroux, ${ }^{\dagger}$ Andrew N. Fitch, ${ }^{\#}$ and Rudy J. M. Konings ${ }^{*}$ \\ ${ }^{\dagger}$ Chimie ParisTech, UPMC Univ. Paris 06, CNRS-UMR 7574, Laboratoire de Chimie de la Matière Condensée de Paris (LCMCP), \\ 75005 Paris, France \\ ${ }^{\ddagger}$ European Commission, Joint Research Centre, Institute for Transuranium Elements, P.O. Box 2340, Karlsruhe, 76125, Germany \\ ${ }^{\S}$ Institut de Chimie Séparative de Marcoule, UMR 5257-CNRS/CEA/UM2/ENSCM, Site de Marcoule, BP 17171,30207 \\ Bagnols/Cèze Cedex, France \\ "Univ Lille Nord France, CNRS, UMR 8181, Unité Catalyse \& Chim Solide, 59652 Villeneuve d'Ascq, France \\ ${ }^{\perp}$ Department of Chemistry, “Al.I. Cuza” University, 11-Carol I Boulevard, 700506 Iasi, Romania \\ \#European Synchrotron Radiation Facility, BP-220, 38043 Grenoble Cedex, France
}

\begin{abstract}
The $A n \mathrm{P}_{2} \mathrm{O}_{7}$ diphosphates $(A n=\mathrm{Th}, \mathrm{U}, \mathrm{Np}, \mathrm{Pu})$ have been synthesized by various routes depending on the stability of the $A n^{\mathrm{IV}}$ cation and its suitability for the unusual octahedral environment. Synchrotron and X-ray diffraction, thermal analysis, Raman spectroscopy, and ${ }^{31} \mathrm{P}$ nuclear magnetic resonance reveal them as a new family of diphosphates which probably includes the recently studied $\mathrm{CeP}_{2} \mathrm{O}_{7}$. Although they adopt at high temperature the same cubic archetypal cell as the other known $\mathrm{MP}_{2} \mathrm{O}_{7}$ diphosphates, they differ by a very faint triclinic distortion at room temperature that results from an ordering of the $\mathrm{P}_{2} \mathrm{O}_{7}$ units, as shown using high-resolution synchrotron diffraction for $\mathrm{UP}_{2} \mathrm{O}_{7}$. The uncommon triclinic-cubic phase transition is first order, and its temperature is very sensitive to the ionic radius of $A n^{\mathrm{IV}}$. The conflicting effects which control the thermal variations of the $\mathrm{P}-\mathrm{O}-\mathrm{P}$ angle are responsible for a strong expansion of the cell followed by a contraction at higher temperature. This inversion of expansion occurs at a temperature significantly higher than the phase transition, at

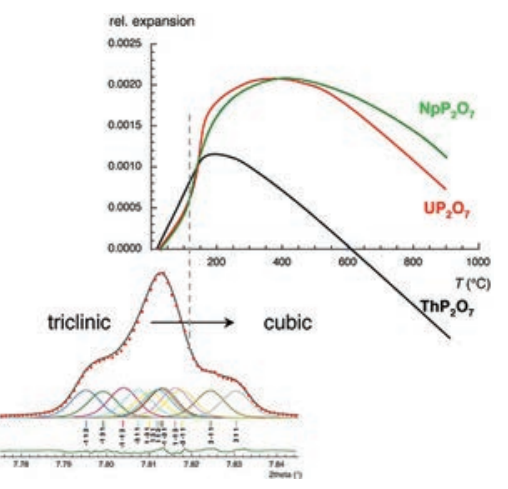
variance with the parent compounds with smaller $\mathrm{M}^{\mathrm{IV}}$ cations in which the two phenomena coincide. As shown by various approaches, the $\mathrm{P}-\mathrm{O}_{\mathrm{b}}-\mathrm{P}$ linkage remains bent in the cubic form.
\end{abstract}

\section{INTRODUCTION}

In 1935, Levi and Peyronel revealed the existence of a wide family of $\mathrm{M}^{\mathrm{IV}} \mathrm{P}_{2} \mathrm{O}_{7}$ diphosphates, whose structure can be thought of as a rock-salt-like array of $\mathrm{P}_{2} \mathrm{O}_{7}$ units and $\mathrm{M}^{\mathrm{IV}}$ cations in octahedral coordination. ${ }^{1,2}$ Since then an abundant amount of literature has established the ability of this structure to host nearly any tetravalent cation, including some which almost never occur in a six-oxygen coordination like the two end members: $\mathrm{Si}^{3}$ and $\mathrm{Th},{ }^{4,5}$ despite the huge difference in size $\left(r\left(\mathrm{Si}^{\mathrm{IV}}\right)=0.40 \AA ; r\left(\mathrm{Th}^{\mathrm{IV}}\right)=0.94 \AA\right.$, coord. $\left.\mathrm{VI}^{6}\right)$.

In the early works the structure at room temperature was believed to be cubic (space group $P a-3, Z=4, a \approx 8 \AA$ ), but since the late $1960 \mathrm{~s}$, progress in diffraction techniques and other analytical methods have revealed superstructures for $\mathrm{M}=$ $\mathrm{Si}^{3,7} \mathrm{Ti}^{8,9}$ and $\mathrm{Ce}^{10}$ and cell distortions for $\mathrm{M}=\mathrm{Ge},{ }^{11} \mathrm{Sn},{ }^{12}$ and $\mathrm{Ce}^{13}$ resulting from an ordering of the bent $\mathrm{P}_{2} \mathrm{O}_{7}$ units. In this family, $\mathrm{ZrP}_{2} \mathrm{O}_{7}$ offers perhaps one of the most remarkable examples of a long-debated crystal structure. After Hagman et al. $(1969)^{14}$ and Chaunac $(1971)^{15}$ confirmed Levi's model, Khosrovani et al. proposed in 1996 a $3 \times 3 \times 3$ superstructure, still cubic, exhibiting unusual $\mathrm{P}-\mathrm{O}-\mathrm{P}$ angles of $180^{\circ} .{ }^{16}$ Ten years later, Birkedal et al. ${ }^{17}$ and Stinton et al. ${ }^{18}$ demonstrated that the superstructured cell was orthorhombic with all the P$\mathrm{O}-\mathrm{P}$ linkages bent at $141-149^{\circ}$. However, despite the validity of Levi's model at room temperature often being questioned, most authors agree about the existence of this simple cubic form at high temperature, ${ }^{13,19,20}$ which will be referred to in the following as the "archetype".

Although less known than the other members of the family, the $A n \mathrm{P}_{2} \mathrm{O}_{7}(A n=\mathrm{Th}, \mathrm{U}, \mathrm{Np}, \mathrm{Pu})$ diphosphates have been studied during the past two decades in the frame of the exploration of the $A n \mathrm{O}_{2}-\mathrm{P}_{2} \mathrm{O}_{5}$ systems ${ }^{21-23}$ to evaluate the interest of phosphate-based matrices in the back-end of the nuclear fuel cycle. ${ }^{24-28}$ First considered as potential host matrices for the long-term minor actinides' immobilization, these diphosphates showed two critical structural weaknesses, i.e., the presence of a bridging oxygen $\left(\mathrm{O}_{\mathrm{b}}\right.$ in the $\mathrm{O}_{3} \mathrm{P}-\mathrm{O}_{\mathrm{b}}-\mathrm{PO}_{3}$ unit) prone to protonation and the limited thermal stability of the big actinide cations in octahedral coordination. ${ }^{29}$ Besides, 
development of spent nuclear fuel reprocessing led to the reinvestigation of the chemistry of actinide phosphates as products of the reaction with tributyl phosphate. However, available data remain limited because of the radioactivity hazards which restrict considerably both their availability and their use.

The actinide diphosphates also show several points of fundamental interest. From a structural point of view, the presence of high-radius cations like $\mathrm{U}^{\mathrm{IV}}$ and particularly $\mathrm{Th}^{\mathrm{IV}}$ in a 6-fold oxygen environment stable up to about $1000{ }^{\circ} \mathrm{C}$ is an exceptional feature from which unusual physical properties can be expected, like thermal expansion. In contrast to the other diphosphates, the title compounds are still considered to adopt Levi's simple cubic model. ${ }^{29-32}$ However, routine X-ray powder diffraction performed during our preliminary work showed anomalous peak profiles which suggested a complex and still unknown modification of the archetype. Synchrotron diffraction has been used to address this point.

In previous work, the room-temperature forms, supposedly cubic, were generally referred to as " $\alpha$ " to be distinguished from a would-be orthorhombic high-temperature variety termed $\beta .^{33-35}$ The transition between both phases was reported to be reversible between 800 and $1000{ }^{\circ} \mathrm{C}$ for $\mathrm{ThP}_{2} \mathrm{O}_{7}$ and near 750 ${ }^{\circ} \mathrm{C}$ for $\mathrm{UP}_{2} \mathrm{O}_{7}{ }^{35}$ However, despite being similar in composition to a diphosphate, the $\beta$ form recently appeared to correspond to isomeric $A n_{2}\left(\mathrm{PO}_{4}\right)\left(\mathrm{P}_{3} \mathrm{O}_{10}\right)$ instead. ${ }^{36}$ Moreover, the symmetry of the room-temperature form of the true $A n \mathrm{P}_{2} \mathrm{O}_{7}$ diphosphates appears questionable. Thus, this misleading terminology will be replaced in the present work by naming the different forms after their crystal system, for example, $c$ $\mathrm{UP}_{2} \mathrm{O}_{7}$ for the cubic one.

Indeed, nothing was known about a possible polymorphism in spite of two early dilatometric experiments made several decades ago on $\mathrm{ThP}_{2} \mathrm{O}_{7}{ }^{5}$ and $\mathrm{UP}_{2} \mathrm{O}_{7}{ }^{37}$ ceramics, which demonstrated an inversion of the thermal expansion. Now, such a phenomenon, one of the most popular topics related to the other $\mathrm{MP}_{2} \mathrm{O}_{7},{ }^{19,20,38}$ is commonly associated to a probable phase transition to the archetype form. However, White et al., studying recently $\mathrm{CeP}_{2} \mathrm{O}_{7}$, suggested that this transition occurred below the inversion temperature. ${ }^{13}$ In the present work, a wide range of analytical methods was used in order to contribute to this debate by measuring precisely the thermal expansion of the $A n \mathrm{P}_{2} \mathrm{O}_{7}$ and characterizing the evolution of their crystal structure.

\section{EXPERIMENTAL SECTION}

Owing to the toxicity and/or low radioactivity of the title compounds, all experiments except NMR and synchrotron diffraction on samples containing thorium or depleted uranium were carried out with special facilities in gloveboxes for radionuclides at ITU and ICSM.

Synthesis. Powder samples of the compounds were obtained following different synthesis routes adapted to both the stability of the $A n^{\mathrm{IV}}$ cation in the octahedral environment and its tendency to oxidize or reduce. All actinide reagents were previously laboratory prepared.

As stated previously, pure $\mathrm{ThP}_{2} \mathrm{O}_{7}$ seems difficult to obtain by the solid state route, which yields $\mathrm{Th}_{4}\left(\mathrm{PO}_{4}\right)_{4}\left(\mathrm{P}_{2} \mathrm{O}_{7}\right)$, or by precipitation and evaporation (aqueous thorium nitrate and concentrated acid phosphate solution in 1:2 proportions), which leads to a mixture of $\mathrm{ThP}_{2} \mathrm{O}_{7}$ and $\mathrm{Th}_{2}\left(\mathrm{PO}_{4}\right)\left(\mathrm{P}_{3} \mathrm{O}_{10}\right){ }^{29}$ The two unwanted products, which have no known homologues with other $A n^{\mathrm{IV}}$ cations, offer an eightoxygen coordination for $\mathrm{Th}^{\mathrm{IV}}$, undoubtedly more suitable than the 6fold one in $\mathrm{ThP}_{2} \mathrm{O}_{7}$, which is indeed a unique case in the chemistry of thorium. Thus, $\mathrm{Th}\left(\mathrm{HPO}_{4}\right)_{2} \cdot 2 \mathrm{H}_{2} \mathrm{O}$ was first synthesized from a stoichiometric mixture of $\mathrm{Th}\left(\mathrm{NO}_{3}\right)_{4} \cdot 5 \mathrm{H}_{2} \mathrm{O}$ and $\mathrm{NH}_{4} \mathrm{H}_{2} \mathrm{PO}_{4}$ (Alfa Aesar, 99\%), placed in a PTFE closed container, and heated on a sand bath at $150{ }^{\circ} \mathrm{C}$ for 1 week. ${ }^{22}$ The precipitate was recovered by centrifugation, washed several times with deionized water and ethanol, dried in an oven, and finally heated at $800{ }^{\circ} \mathrm{C}$ for $10 \mathrm{~h}$.

$\mathrm{Pu}^{\mathrm{IV}}$, contrary to $\mathrm{Th}^{\mathrm{IV}}, \mathrm{U}^{\mathrm{IV}}$, and $\mathrm{Np}^{\mathrm{IV}}$, readily reduces into $\mathrm{Pu}^{\mathrm{III}}$, especially when bonded to phosphate to form the monazite-like $\mathrm{PuPO}_{4},{ }^{39}$ so the synthesis of $\mathrm{PuP}_{2} \mathrm{O}_{7}$ by solid state reaction from $\mathrm{PuO}_{2}$ and $\mathrm{NH}_{4} \mathrm{H}_{2} \mathrm{PO}_{4}$ at various temperatures led to significant amounts of $\mathrm{PuPO}_{4}$ impurities. The synthesis was performed by wet chemistry in a similar way to that proposed by $\mathrm{De}$ et al. for $\mathrm{ThP}_{2} \mathrm{O}_{7}{ }^{40} \mathrm{~A}{ }^{239} \mathrm{Pu}\left(\mathrm{NO}_{3}\right)_{4}$ solution $\left(115.3 \mathrm{mg} \cdot \mathrm{ml}^{-1}\right)$ from reactor-grade plutonium was added slowly to a 4-fold excess of $0.74 \mathrm{M} \mathrm{H}_{3} \mathrm{PO}_{4}$ in a Teflon beaker and held under a watch glass at $\sim 80{ }^{\circ} \mathrm{C}$ for $47 \mathrm{~h}$ on a magnetic stirrer. Further treatments were analogous to those for $\mathrm{ThP}_{2} \mathrm{O}_{7}$. The powder obtained appeared inhomogeneous with respect to color: greenish on top and gray at the bottom. These fractions were collected separately as far as possible but eventually appeared similar by XRD. Minor impurities were observed in both, which might be plutonium homologues of those observed for the thorium compound. ${ }^{29}$

$\mathrm{NpP}_{2} \mathrm{O}_{7}$ was synthesized by solid state reactions using stoichiometric amounts of high-purity ${ }^{237} \mathrm{NpO}_{2}$ and $\left(\mathrm{NH}_{4}\right)_{2} \mathrm{HPO}_{4}$ in a nitrogen-filled glovebox. Starting materials were thoroughly mixed in agate mortar and then heated in an alumina crucible under air at 980 ${ }^{\circ} \mathrm{C}$ for $24 \mathrm{~h}$.

The $\mathrm{UP}_{2} \mathrm{O}_{7}$ sample was obtained from the Nuclear Research and Consultancy Group (Petten, The Netherlands), where it was synthesized by heating uranyl monophosphate with a stoichiometric amount of $\mathrm{P}_{4} \mathrm{O}_{10}$ at about $650{ }^{\circ} \mathrm{C}$ in a closed silica tube, as described in detail by Cordfunke et al. ${ }^{41}$

Owing to their sensitivity to moisture, all samples were stored under dry $\mathrm{N}_{2}$ in gloveboxes.

Synchrotron Powder Diffraction. A $4 \mathrm{mg}$ amount of $\mathrm{UP}_{2} \mathrm{O}_{7}$ powder was sealed in a glass capillary $(\varnothing=0.5 \mathrm{~mm})$ and analyzed on the high-resolution diffractometer of the ID31 line of the European Synchrotron Radiation Facility, Grenoble, France. For safety reasons, patterns were recorded only from -173 to $20{ }^{\circ} \mathrm{C}$. Main acquisition parameters are reported in Table 1 . More instrumental details are available in ref 42 .

Table 1. Main Acquisition and Refinement Parameters and Crystallographic Data for $t$ - and $c-\mathrm{UP}_{2} \mathrm{O}_{7}$

\begin{tabular}{|c|c|c|}
\hline form & $t-\mathrm{UP}_{2} \mathrm{O}_{7}$ & $c-\mathrm{UP}_{2} \mathrm{O}_{7}$ \\
\hline temperature & $25{ }^{\circ} \mathrm{C}$ & $600{ }^{\circ} \mathrm{C}$ \\
\hline diffractometer & ESRF ID31 & Siemens D8 \\
\hline wavelength, monochromator & $0.35409 \AA, \mathrm{Si}(111)$ & $1.5405 \AA, \mathrm{Ge}(111)$ \\
\hline $2 \theta$ scan range, step & $2.3-30^{\circ}, 0.001^{\circ}$ & $15-118^{\circ}, 0.007^{\circ}$ \\
\hline obsd reflns & 10627 & 164 \\
\hline $\begin{array}{l}\text { I-dependent, profile } \\
\text { parameters }\end{array}$ & 125,13 & 11,6 \\
\hline \multirow[t]{6}{*}{ conventional reliability factors } & $\mathrm{R}_{\mathrm{P}}=0.078$ & $\mathrm{R}_{\mathrm{P}}=0.075$ \\
\hline & $\mathrm{R}_{\mathrm{WP}}=0.11$ & $\mathrm{R}_{\mathrm{WP}}=0.099$ \\
\hline & $\mathrm{R}_{\text {Bragg }}=0.037$ & $\mathrm{R}_{\text {Bragg }}=0.056$ \\
\hline & $R_{\text {exp }}=0.065$ & $R_{\text {exp }}=0.047$ \\
\hline & $\mathrm{R}_{\mathrm{F}}=0.093$ & $\mathrm{R}_{\mathrm{F}}=0.048$ \\
\hline & $\chi^{2}=2.8$ & $\chi^{2}=4.6$ \\
\hline cryst syst, space group & triclinic, $P 1$ (no. 1) & cubic, $P a \overline{3}$ (no. 205) \\
\hline \multirow[t]{7}{*}{ cell params ${ }^{a}$, volume } & $a=8.6180(2) \AA$ & $a=8.6387(3) \AA$ \\
\hline & $b=8.6326(3) \AA$ & $V=644.69(7) \AA^{3}$ \\
\hline & $c=8.6349(2) \AA$ & \\
\hline & $\alpha=89.929(2)^{\circ}$ & \\
\hline & $\beta=90.174(2)^{\circ}$ & \\
\hline & $\gamma=90.089(2)^{\circ}$ & \\
\hline & $V=642.40(3) \AA^{3}$ & \\
\hline $\mathrm{fw}, Z$, density & $411.96,4,4.26$ & $411.96,4,4.24$ \\
\hline
\end{tabular}

${ }^{a}$ To take into account possible systematic errors, esd's given by the refinement program have been multiplied by 10 . 
High-Temperature X-ray Powder Diffraction. Diffraction experiments above room temperature (HTXRD) were carried out under $\mathrm{He}$ flow on a conventional diffractometer equipped with a heating platinum holder. Temperature was calibrated according to the transition point of $\mathrm{UP}_{2} \mathrm{O}_{7}$, measured by DSC. Samples were studied at various temperatures from room temperature to $800{ }^{\circ} \mathrm{C}\left(500{ }^{\circ} \mathrm{C}\right.$ for $\mathrm{PuP}_{2} \mathrm{O}_{7}$ because of the reduction of $\mathrm{Pu}^{\mathrm{IV}}$ under $\mathrm{He}$ that led to formation of $\mathrm{Pu}^{\mathrm{III}} \mathrm{PO}_{4}$ ) with counting times and scan ranges depending on whether the pattern was to be used for measuring the cell parameters and peak width or refine the crystal structure (only in the cubic model). See Table 1 for experimental conditions in the latter case. A complete series of long XRD measurements was carried out on $\mathrm{ThP}_{2} \mathrm{O}_{7}$ in order to follow the thermal evolution of the $\mathrm{P}-\mathrm{P}$ and $\mathrm{Th}-$ $\mathrm{P}$ distances.

Differential Scanning Calorimetry. DSC measurements of $\mathrm{UP}_{2} \mathrm{O}_{7}$ were performed under $\mathrm{He}$ flow at a heating/cooling rate of $15{ }^{\circ} \mathrm{C} \mathrm{min}{ }^{-1}$ on a Netzsch STA 409 A Cell analyzer.

${ }^{31} \mathrm{P}$ Nuclear Magnetic Resonance. ${ }^{31} \mathrm{P}$ NMR experiments on $\mathrm{UP}_{2} \mathrm{O}_{7}$ were conducted using a Bruker $400 \mathrm{MHz}$ spectrometer operating at a Larmor frequency of $161.97 \mathrm{MHz}$. The sample was packed in a $4 \mathrm{~mm}$ zirconia rotor and spun at a magic-angle spinning (MAS) rate of $9 \mathrm{kHz} .{ }^{31} \mathrm{P}$ chemical shifts were referenced to the signal from $\mathrm{H}_{3}{ }^{31} \mathrm{PO}_{4}(80 \%$ aqueous solution) at $0 \mathrm{ppm}$. Temperature calibration was made prior to experiments using the temperature dependence of the ${ }^{207} \mathrm{~Pb}$ resonance of $\mathrm{PbNO}_{3} \cdot{ }^{43,44}$ Correction factors up to $-25^{\circ} \mathrm{C}$ at maximum temperature $\left(167^{\circ} \mathrm{C}\right)$ were obtained. The actual sample temperature may also be higher because of frictional heating provoked by the high MAS speed. Our temperature calibration showed that changing the MAS speed at $167{ }^{\circ} \mathrm{C}$ from 5 to $9 \mathrm{kHz}$ resulted in a temperature increase of less than $5{ }^{\circ} \mathrm{C}$. All temperatures given in the following have been corrected taking into account the previous observations.

High-Temperature Micro-Raman Spectroscopy. HT- $\mu$-Raman spectra of $\mathrm{ThP}_{2} \mathrm{O}_{7}$ and $\mathrm{UP}_{2} \mathrm{O}_{7}$ were collected with a Horiba-Jobin Yvon Aramis apparatus equipped with an edge filter and using a Nd:YAG laser $(\lambda=532 \mathrm{~nm}, 45 \mathrm{~mW})$. Samples were placed in a platinum crucible and brought to the chosen temperature at a rate of 5 ${ }^{\circ} \mathrm{C} \min ^{-1}$. HT- $\mu$-Raman spectra were then recorded after a few minutes of thermal stabilization. The laser beam was focused on the sample using an Olympus BX41 microscope, resulting in a spot area of about $1 \mu \mathrm{m}^{2}$. Several locations were investigated at the surface of each sample, usually considering a dwell time of $30 \mathrm{~s}$ and an average of 4 scans. Band areas were finally determined from a Gaussian-Lorenzian fitting using the Peakfit 4.12 software.

\section{RESULTS AND DISCUSSION}

Crystal Structures of $t$ - and $c-U_{2} \mathrm{O}_{7}$. The search for the crystal unit cell in the low-temperature form was initiated by careful examination of the synchrotron diffraction pattern taken at $-173{ }^{\circ} \mathrm{C}$, which exhibits the strongest deviation from the cubic model. No other peaks except those corresponding to residual $\mathrm{U}\left(\mathrm{UO}_{2}\right)\left(\mathrm{PO}_{4}\right)_{2}{ }^{45}(<0.7 \%)$ were observed, thus demonstrating the absence of a superstructure. Electron diffraction recently led to the same conclusion for $\mathrm{ThP}_{2} \mathrm{O}_{7}{ }^{29}$ However, all peaks of the prototype cell showed anomalous profiles indicating a very faint cell distortion. The $a, b$, and $c$ cell edges were evaluated from the 3 -fold split 200 reflection and then used for a Le Bail (profile matching) refinement with Fullprof $^{46}$ to determine the $\alpha, \beta$, and $\gamma$ angles. Although these parameters only faintly deviate from the archetype, the triclinic nature of the low-temperature form $\left(t-\mathrm{UP}_{2} \mathrm{O}_{7}\right)$ appears clearly in the complex splitting of all the reflections except those with indices $(h 00),(0 k 0)$, and (00l) (Figure 1).

In the archetype form, the single bridging oxygen $\mathrm{O}_{b}$ of the $\mathrm{P}-\mathrm{O}_{\mathrm{b}}-\mathrm{P}$ linkage is often considered to lie on the inversion center at $(1 / 2,1 / 2,1 / 2),{ }^{15,29,47}$ resulting in anomalous short bridging $\mathrm{P}-\mathrm{O}_{\mathrm{b}}$ distances $(1.48-1.52 \AA)$ and high thermal

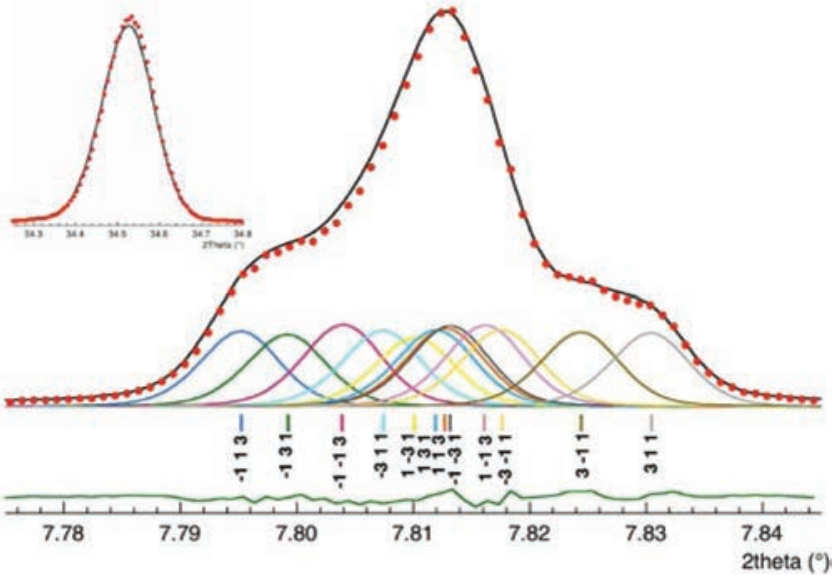

Figure 1. Twelve-fold splitting of the 311 reflection in the final Rietveld plot of the synchrotron diffraction pattern of $t-\mathrm{UP}_{2} \mathrm{O}_{7}$ (red dots, experimental; black line, calculated, sum of the 12 peaks; lower green plot, difference curve). (Inset) Same region observed by laboratory XRD.

factors for $\mathrm{O}_{\mathrm{b}}\left(B_{\text {iso }}=7-13 \AA^{2}\right)$. In a more realistic model, $\mathrm{O}_{\mathrm{b}}$ is supposed to be distributed around this special position to take into account the bending of the $\mathrm{P}-\mathrm{O}_{\mathrm{b}}-\mathrm{P}$ linkage commonly observed in diphosphates. ${ }^{48,49}$ Should these units order at low temperature, then the inversion center disappears. Thus, we built the starting triclinic model by expanding the atomic positions of the cubic set into the $P 1$ space group, that is, with the 40 atoms of the $4 \mathrm{UP}_{2} \mathrm{O}_{7}$ units in general positions. The refinement was performed with Fullprof. Despite the high number of peaks measured, the overlaps resulting from the pseudosymmetry and the strong contrast between the electron densities of $\mathrm{U}$ and $\mathrm{O}$ led us to impose soft restraints on the highly predictable $\mathrm{P}-\mathrm{O}$ and $\mathrm{P}-\mathrm{O}_{\mathrm{b}}$ distances. Using Brese's bond valence parameters ${ }^{50}$ and assuming bond strengths of 1 vu for $\mathrm{P}-\mathrm{O}_{\mathrm{b}}$ and $4 / 3$ vu for $\mathrm{P}-\mathrm{O}$, the restraints were set, respectively, at 1.60 and $1.50 \AA$. Likewise, one common thermal factor was refined for all $8 \mathrm{P}$ atoms, 1 for the 24 nonbridging oxygens, and 1 for the 4 bridging oxygens. The refined crystal structure is shown in Figure 2.

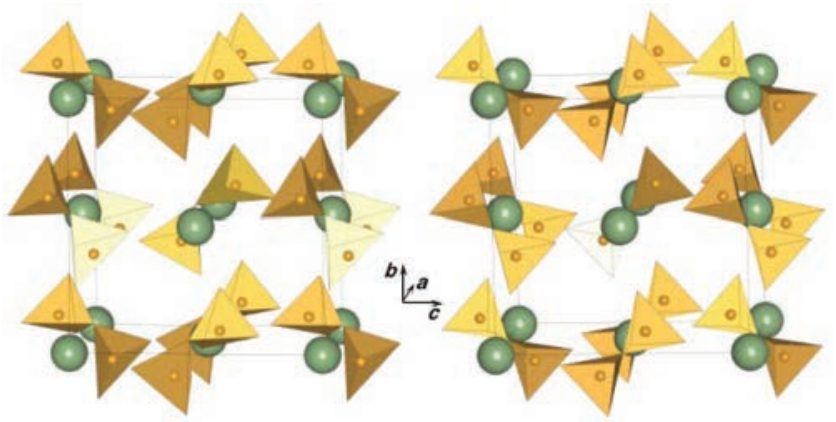

Figure 2. Crystal structures of triclinic $t-\mathrm{UP}_{2} \mathrm{O}_{7}$ (left) and cubic $c$ $\mathrm{UP}_{2} \mathrm{O}_{7}$ (right, showing the oxygen atoms on their mean position).

The unit cell parameters of the $t$ form confirm the nearly cubic geometry that was not detected in previous studies on $\mathrm{UP}_{2} \mathrm{O}_{7}$, ${ }^{2,30}$ based only on conventional XRD. The final positions of the cations are very close to those of the cubic model $(\Delta x a, y b, z c \leq 0.017(5) \AA$ for uranium and $\leq 0.138(6)$ $\AA$ for phosphorus), so the faint triclinic distortion of the cell 
results in a splitting into peaks of similar intensities, as shown by decomposition of the cubic 311 peak into 12 nearly equal reflections (Figure 1). The shifts of the oxygen atoms are far stronger, but the unrestrained $\mathrm{U}-\mathrm{O}$ distances and $\mathrm{O}-\mathrm{P}-\mathrm{O}$ angles are satisfactory (Table 2 ).

Table 2. Selected Cation-Anion Distances and Angles for $\boldsymbol{t}$ $\mathrm{UP}_{2} \mathrm{O}_{7}\left(-173,25^{\circ} \mathrm{C}\right)$ and $c-\mathrm{UP}_{2} \mathrm{O}_{7}\left(600{ }^{\circ} \mathrm{C}\right)^{a}$

\begin{tabular}{lccc}
$T\left({ }^{\circ} \mathrm{C}\right)$ & $\mathrm{U}-\mathrm{O}(\AA)$ & $\mathrm{P}-\mathrm{O}_{\mathrm{b}}-\mathrm{P}(\mathrm{deg})^{b}$ & \multicolumn{1}{c}{$\mathrm{U}-\mathrm{P}(\AA)$} \\
-173 & $2.20(2)-2.27(3)$ & $135(2)-140(2)$ & $3.57(1)-3.76(1)$ \\
25 & $2.21(3)-2.28(3)$ & $136(2)-142(3)$ & $3.55(1)-3.73(1)$ \\
600 & $2.276(6)$ & $139(2)$ & $3.656(2)$ \\
\multicolumn{1}{c}{$T\left({ }^{\circ} \mathrm{C}\right)$} & $\mathrm{P}-\mathrm{O}_{\mathrm{b}}(\AA)$ & $\mathrm{P}-\mathrm{O}(\AA)$ \\
\multicolumn{2}{c}{-173} & $1.60(5)-1.61(4)$ & $1.50(3)-1.51(4)$ \\
25 & \multicolumn{2}{c}{$1.60(3)-1.61(3)$} & $1.50(3)-1.51(3)$ \\
600 & \multicolumn{1}{c}{$1.604(4)$} & $1.402(5)$
\end{tabular}

${ }^{a} \mathrm{O}_{\mathrm{b}}$ is a bridging oxygen and $\mathrm{O}$ a nonbridging one. ${ }^{b}$ Esd's are underestimated because of the restraints on the $\mathrm{P}-\mathrm{O}_{\mathrm{b}}$ distances.

The four independent $\mathrm{P}_{2} \mathrm{O}_{7}$ units show a staggered conformation with a strong bending of the $\mathrm{P}-\mathrm{O}_{\mathrm{b}}-\mathrm{P}$ linkages. The bond angles are in good agreement with those determined from the Raman spectra using Lazarev's empirical correlation rule based on the $\nu_{\mathrm{S}}\left(\mathrm{P}-\mathrm{O}_{\mathrm{b}}-\mathrm{P}\right)$ and $\nu_{\mathrm{AS}}\left(\mathrm{P}-\mathrm{O}_{\mathrm{b}}-\mathrm{P}\right)$ stretching wavenumbers (about $140^{\circ}$ at $20{ }^{\circ} \mathrm{C}$ ). ${ }^{51}$ They are also comparable to the $137^{\circ}$ angle of Cabeza's room-temperature cubic model featuring split positions for $\mathrm{O}_{\mathrm{b}} \cdot{ }^{30}$ The bending of the $\mathrm{P}-\mathrm{O}-\mathrm{P}$ linkages results in a strong distortion of the $\mathrm{PO}_{4}$ tetrahedra. Typically, as shown in Figure 3 for the $\mathrm{P}_{2} \mathrm{O}_{7}$ unit

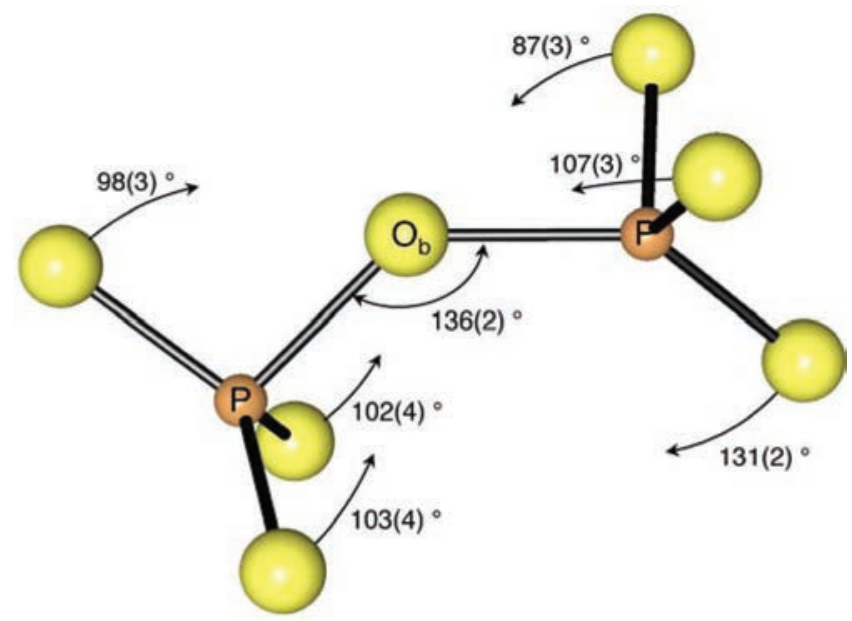

Figure 3. $\mathrm{P}_{2} \mathrm{O}_{7}$ unit near $(1 / 2,1 / 2,1 / 2)$ in $t-\mathrm{UP}_{2} \mathrm{O}_{7}$ with associated $\mathrm{O}_{\mathrm{b}}-\mathrm{P}-\mathrm{O}$ and $\mathrm{P}-\mathrm{O}_{\mathrm{b}}-\mathrm{P}$ angles.

near $(1 / 2,1 / 2,1 / 2)$, the $\mathrm{O}_{b}-\mathrm{P}-\mathrm{O}$ angles involving a nonbridging $\mathrm{O}$ on the same side as the opposite phosphorus are higher than the other ones. This asymmetric distortion justifies a posteriori the choice of acentric space group $P 1$ instead of $P-$ 1 . This ordered model is also validated by the moderate thermal factor of the bridging oxygens $\left(B_{\text {iso }}=5.0(4) \AA^{2}\right.$ at $20{ }^{\circ} \mathrm{C}$, common to the four $\mathrm{O}_{\mathrm{b}}$ 's), comparable to that of the nonbridging ones $\left(3.9(1) \AA^{2}\right)$.

As will be shown below, $\mathrm{UP}_{2} \mathrm{O}_{7}$ transforms to the cubic archetype form $\left(c-\mathrm{UP}_{2} \mathrm{O}_{7}\right)$ at high temperature. This structure was refined from a conventional $\mathrm{X}$-ray pattern on the basis of Levi's cubic model (space group $P a-3, \mathrm{U}(0,0,0), \mathrm{P}(x, x, x)$ and nonbridging $\mathrm{O}(x, y, z))$, but particular attention was paid to the location of bridging $\mathrm{O}_{\mathrm{b}}$ (near $\left.(1 / 2,1 / 2,1 / 2)\right)$, which monitors the bending of the unique $\mathrm{P}-\mathrm{O}_{\mathrm{b}}-\mathrm{P}$ linkage. A Fourier synthesis of the observed structure factors at $600{ }^{\circ} \mathrm{C}$ was made introducing all atoms but $\mathrm{O}_{\mathrm{b}}$ to obtain an electron density map of the (111) mid-distance plane perpendicular to the P-P (3-fold) axis (Figure 4). This reveals a dense and

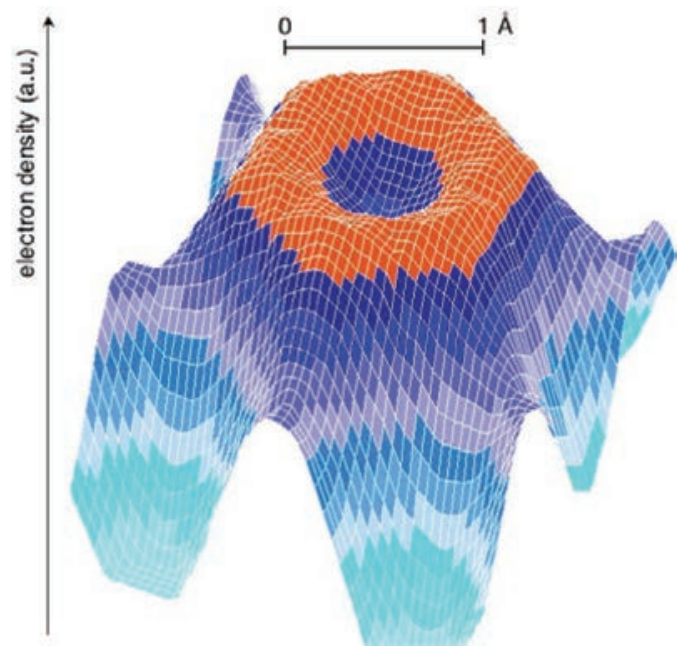

Figure 4. $c-\mathrm{UP}_{2} \mathrm{O}_{7}$ : annular distribution of $\mathrm{O}_{\mathrm{b}}$ in the (111) plane around the $(1 / 2,1 / 2,1 / 2)$ inversion center shown by the $3 \mathrm{D}$ electron density map at $600{ }^{\circ} \mathrm{C}$.

homogeneous annular zone centered on $(1 / 2,1 / 2,1 / 2)$, which accounts for the delocalization of $\mathrm{O}_{\mathrm{b}}$ about $0.56 \AA$ away from the inversion center. This distribution of $\mathrm{O}_{b}$ in the archetype confirms that a ring-like model, even discontinuous, with offcentered positions is more satisfactory than an ellipsoidal model with a maximum probability of the presence at the center, in agreement with the absence of $\pi$ bonding. $\mathrm{P}-\mathrm{O}_{\mathrm{b}}-\mathrm{P}$ was estimated at about $139^{\circ}$ on the basis of the $\mathrm{P}$...P distance, assuming $\mathrm{P}-\mathrm{O}_{\mathrm{b}}=1.60 \AA$ Although the nonbridging oxygen atoms are also affected by the disorder as shown by the anomalous short $\mathrm{P}-\mathrm{O}$ distances, they are too close to the heavy uranium atoms to be observed in the same way as $\mathrm{O}_{\mathrm{b}}$.

Other $\mathrm{AnP}_{2} \mathrm{O}_{7}$. According to $\mathrm{XRD}$, the other $A n \mathrm{P}_{2} \mathrm{O}_{7}$ compounds $(A n=\mathrm{Th}, \mathrm{Np}, \mathrm{Pu})$ also exhibit broadened peaks without any evidence of a superstructure, but the distortion appears more intense when the $A n^{\mathrm{IV}}$ cation is small (i.e., extremely faint for $\mathrm{ThP}_{2} \mathrm{O}_{7}$ but clearly visible for $\mathrm{PuP}_{2} \mathrm{O}_{7}$ ). On this basis, the $A n \mathrm{P}_{2} \mathrm{O}_{7}$ can be supposed to adopt also the triclinic symmetry at room temperature. In this way, the actinide cations differ from smaller ones like $\mathrm{Si}^{\mathrm{IV}}, \mathrm{Ti}^{\mathrm{IV}}$, and $\mathrm{Zr}^{\mathrm{IV}}$, whose diphosphates have a $3 \times 3 \times 3$ cubic or orthorhombic superstructure. ${ }^{3,8,17,18}$ On the other hand, White et al. using synchrotron diffraction recently noted a faint distortion of the $\mathrm{CeP}_{2} \mathrm{O}_{7}$ cell $^{13}$ and proposed a triclinic cell with parameters remarkably analogous to those of $\mathrm{UP}_{2} \mathrm{O}_{7}$, considering both the metric distortion $(0.20 \%$ vs $0.20 \%$ for the latter) and the maximum deviation from the right angle $\left(0.17^{\circ}\right.$ vs $\left.0.17^{\circ}\right)$, also with two nearly equal cell edges. Thus, owing to the similar ionic radius of the tetravalent cation $\left(r \mathrm{Ce}^{\mathrm{IV}}=1.01 \AA\right.$; $1.00 \leq$ $r A n^{\mathrm{IV}} \leq 1.08 \AA$ in 6 -fold coordination $\left.{ }^{6}\right), \mathrm{CeP}_{2} \mathrm{O}_{7}$ is probably isotypic with the title compounds.

Triclinic-Cubic Phase Transition of $\mathrm{UP}_{2} \mathrm{O}_{7}$. A single endothermal peak (starting $155^{\circ} \mathrm{C}$, rev. $155^{\circ} \mathrm{C}$ ) is visible on 
the DSC curve (Figure 5). Although intense, this transition shows a negligible hysteresis. HTXRD, less accurate than

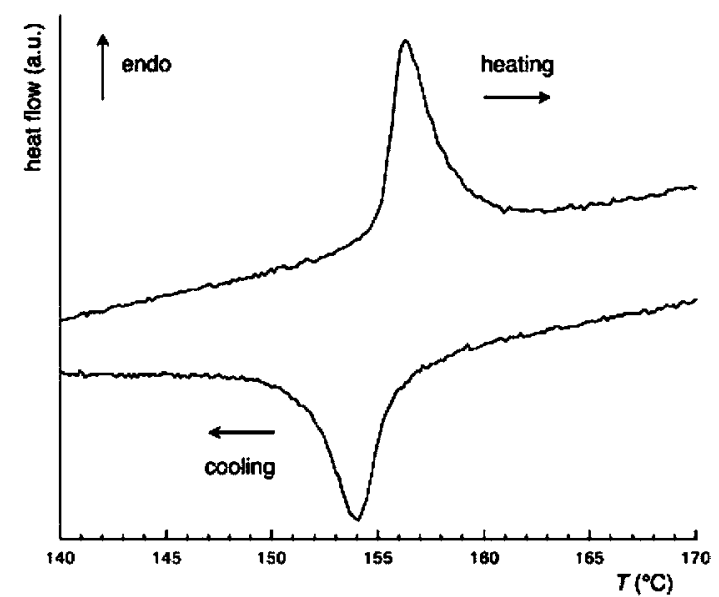

Figure 5. Differential scanning calorimetry analysis of $\mathrm{UP}_{2} \mathrm{O}_{7}$ : heating (upper) and cooling (lower) plots.

synchrotron diffraction, does not allow deconvolution of the strongly overlapped peaks of the triclinic form and following the thermal evolution of the six cell parameters. However, measurement of the integral width (IFWHM) of four strong composite peaks revealed a continuous decrease on heating, followed by a sudden break near the transition point (Figure 6).

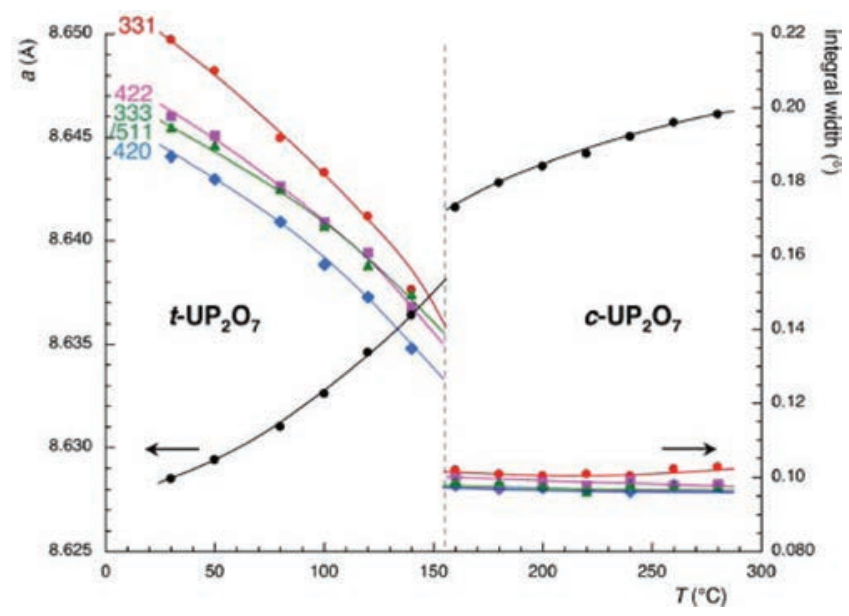

Figure 6. Thermal variation of average cell parameter $a$ (black, left scale) of $\mathrm{UP}_{2} \mathrm{O}_{7}$, and integral widths of four composite diffraction peaks in the $45^{\circ} \leq 2 \theta \leq 57^{\circ}$ range (colors, right scale). $a, h, k$, and $l$ refer to the cubic lattice.

At higher temperatures, all IFWHMs remain nearly constant and equal to that of a corundum standard, thus proving the cubic symmetry of the archetype and the probable absence of an intermediate form. As shown on the same figure, the $t-c$ transition of $\mathrm{UP}_{2} \mathrm{O}_{7}$ is also associated with a marked increase of the cell edge, like for $\mathrm{CeP}_{2} \mathrm{O}_{7},{ }^{13}$ in agreement with the firstorder nature of the transition observed by DSC.

Further evidence of the $t-c$ transition is given by ${ }^{31} \mathrm{P}$ NMR. At low temperature, $t-\mathrm{UP}_{2} \mathrm{O}_{7}$ shows a complex spectrum, where the peaks of the eight independent phosphorus sites present in the triclinic cell strongly overlap (Figure 7). Consequently, a best-fit simulation of the ${ }^{31} \mathrm{P}$ spectra over the whole

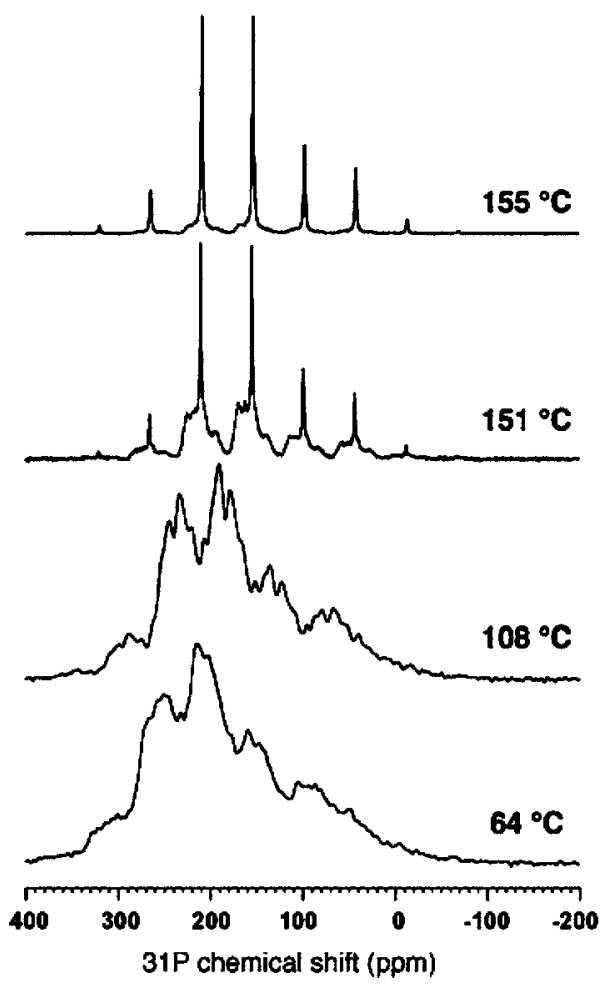

Figure 7. ${ }^{31} \mathrm{P}$ MAS spectra of $\mathrm{UP}_{2} \mathrm{O}_{7}$ as a function of temperature, recorded at a spinning speed of $9 \mathrm{kHz}$.

temperature range could not reasonably be performed. The presence of heavy uranium atoms in the neighborhood also results in an anisotropic chemical shift and numerous rotation bands. The chemical shift appears very sensitive to temperature (0.49 $\mathrm{ppm}{ }^{\circ} \mathrm{C}^{-1}$ from linear fit), probably due to the strong thermal expansion of the cell, as described in the following section. However, the most remarkable thermal transformation of the NMR spectrum is the collapse of each grouping into a single peak upon reaching the cubic form at $155{ }^{\circ} \mathrm{C}$, in agreement with the presence of phosphorus in a single site of the archetype form.

The transition temperatures of the other $A n \mathrm{P}_{2} \mathrm{O}_{7}$ (Table 3) were determined from the inflection point of the expansion curves as shown thereafter. To summarize, this phenomenon can be described according to three criteria: the first-order character, shown by DSC and the discontinuity of the cell volume; the order-disorder character, evidenced by the

Table 3. Effect of the Ionic Radius of $\mathrm{M}^{\mathrm{IV}}$ on the Temperatures of Transition and Inversion of Expansion for Several $\mathrm{MP}_{2} \mathrm{O}_{7}{ }^{a}$

\begin{tabular}{clll} 
cation & $\mathrm{Zr}^{\mathrm{IV}}$ & \multicolumn{1}{c}{$\mathrm{Pu}^{\mathrm{IV}}$} & \multicolumn{1}{c}{$\mathrm{Ce}^{\mathrm{IV}}$} \\
$r_{\mathrm{M}^{\mathrm{IV}}}(\AA)$ & 0.86 & 1.00 & 1.01 \\
$T_{\text {trans }}\left({ }^{\circ} \mathrm{C}\right)$ & 290 & $180(5)$ & $160(10)^{a}$ \\
$T_{\text {inv }}\left({ }^{\circ} \mathrm{C}\right)$ & & 450 & 400 \\
cation & $\mathrm{Np}^{\mathrm{IV}}$ & \multicolumn{1}{c}{$\mathrm{U}^{\mathrm{IV}}$} & $\mathrm{Th}^{\mathrm{IV}}$ \\
$r_{\mathrm{M}^{\mathrm{IV}}}(\AA)$ & 1.01 & 1.03 & 1.08 \\
$T_{\text {trans }}\left({ }^{\circ} \mathrm{C}\right)$ & $160(10)$ & $155(2)$ & $85(5)$ \\
$T_{\text {inv }}\left({ }^{\circ} \mathrm{C}\right)$ & 400 & 330 & 200
\end{tabular}

${ }^{a}$ Our estimation from ref 13 expansion curve; these authors state 115$175{ }^{\circ} \mathrm{C}$. ${ }^{a}$ Inversion temperatures are estimated from the thermal expansion graphs (Figure 9). 
delocalization of $\mathrm{O}_{b}$; the direct change from triclinic to cubic (HTXRD, ${ }^{31} \mathrm{P} \mathrm{NMR}$ ), unless a possible intermediate form occurs in a very narrow range of temperature near the transition. This very uncommon increase of the order of symmetry by a factor of 24 is comparable to that between the cubic $3 \times 3 \times 3$ and the $1 \times 1 \times 1$ cells $^{27}$ but higher than that between the orthorhombic Pbca $3 \times 3 \times 3$ and the cubic $1 \times 1$ $\times 1$ cells of $\mathrm{ZrP}_{2} \mathrm{O}_{7}(\sim 7.1) .{ }^{17,18}$

Thermal Expansion and Contraction. The thermal variation of the cubic/pseudo-cubic cell parameter $a$ was determined for the $A n \mathrm{P}_{2} \mathrm{O}_{7}$ diphosphates $(A n=\mathrm{Th}, \mathrm{U}, \mathrm{Np}, \mathrm{Pu})$ by HTXRD and Rietveld analysis (Figure 8). Except at the

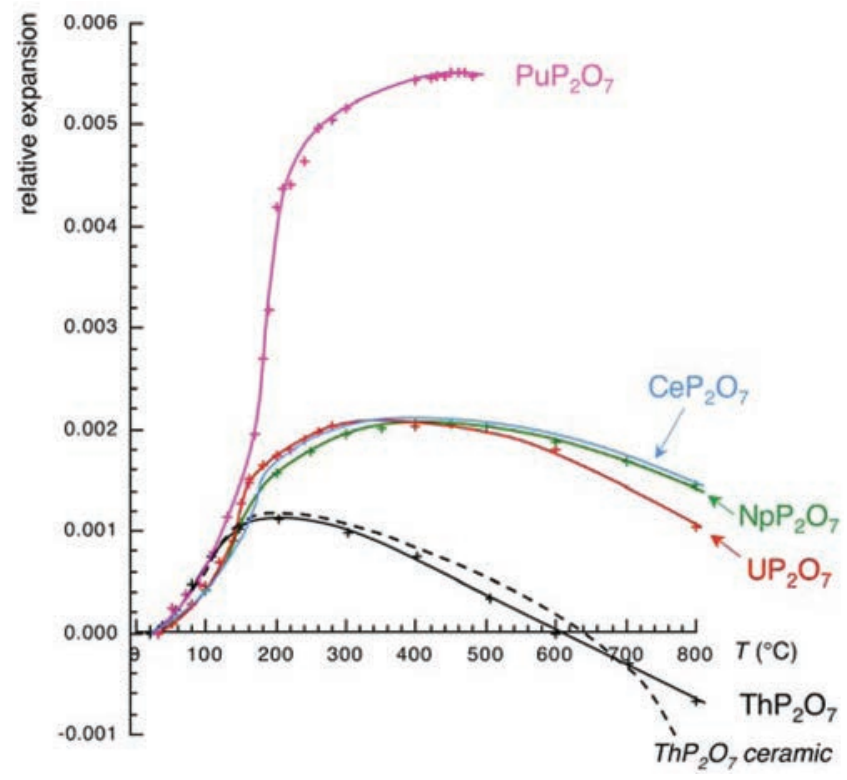

Figure 8. Relative thermal expansion of the cell edges of $A n \mathrm{P}_{2} \mathrm{O}_{7}$ (this work) and $\mathrm{CeP}_{2} \mathrm{O}_{7}$, reproduced from ref 13: (dashed line) dilatometric curve of a $\mathrm{ThP}_{2} \mathrm{O}_{7}$ ceramic reproduced from ref 5 .

highest temperatures, the expansion of the cell edge of $\mathrm{ThP}_{2} \mathrm{O}_{7}$ is in fair agreement with the dilatometric curve recorded on a ceramic by Laud et al. in $1971 .{ }^{5}$ Note also the superimposability of the expansion curves of $\mathrm{NpP}_{2} \mathrm{O}_{7}$ and $\mathrm{CeP}_{2} \mathrm{O}_{7}{ }^{13}$ which, beyond the similarity of the ionic radii $\left(r_{\mathrm{CeIV}}=r_{\mathrm{NpIV}}=1.01 \AA\right)$, can be seen as further evidence for a probable isotypy.

For all the other compounds the coefficient of thermal expansion (CTE) is strongly positive at low temperature and then becomes negative. For instance, $\mathrm{ThP}_{2} \mathrm{O}_{7}$ shows a nearly perfect linear contraction between 400 and $900{ }^{\circ} \mathrm{C}$ with a CTE $\alpha=-3.5 \times 10^{-6}{ }^{\circ} \mathrm{C}^{-1}(R=0.999)$, an extremely rare value over such a wide range. One can compare this behavior to those of $\mathrm{ZrP}_{2} \mathrm{O}_{7}, \mathrm{ZrV}_{2} \mathrm{O}_{7}$, and their solid solutions, ${ }^{19,20,52}$ which also exhibit a strong expansion at low temperature. However, at variance with the $A n \mathrm{P}_{2} \mathrm{O}_{7}$, the transition is marked by a sharp break followed by a moderate but still positive expansion for $\mathrm{ZrP}_{2} \mathrm{O}_{7}$ (a moderate contraction for the vanadium-rich forms). In all the cases, the low or negative expansion observed above the transition point is typical of a thermal rocking of the cornerconnected $\mathrm{MO}_{6}$ and $\mathrm{PO}_{4}$ polyhedra, even though these units sustain some distortion in this phenomenon and cannot be treated as rigid. ${ }^{19}$ However, no explanation was found in the literature for the strong positive expansion that precedes the inversion in all these compounds.
As clearly observed for $\mathrm{UP}_{2} \mathrm{O}_{7}$, the jump in the domain of positive expansion corresponds to the change of symmetry, which obviously occurs below the inversion. Thus, these two phenomena should be considered as definitely distinct in the $A n \mathrm{P}_{2} \mathrm{O}_{7}$, like in $\mathrm{CeP}_{2} \mathrm{O}_{7}{ }^{13}$ On the other hand, the break in the expansion curve of the $\mathrm{ZrP}_{2} \mathrm{O}_{7}-\mathrm{ZrV}_{2} \mathrm{O}_{7}$ solid solutions matches with the transition to the archetypal form. ${ }^{20}$ Indeed, differences in behavior are conceivable because the lowtemperature distortions of these two families of diphosphates are also different.

We tried to explain the remarkable variations of the CTE considering the evolution of the crystal structure over a wide range of temperature. In $\mathrm{ThP}_{2} \mathrm{O}_{7}$, which has the lowest transition point, the triclinic distortion can be considered as faint enough to be ignored in the Rietveld refinement, which was performed therefore in the cubic model, whatever the temperature. Because the oxygen atoms are light, distant from their ideal positions in the triclinic form and subject to strong thermal displacements in the cubic form, the cation-oxygen distances were not considered as reliable enough to follow the evolution of the crystal structure. Conversely, the unambiguous positions of $\mathrm{Th}$ and $\mathrm{P}$ in the two domains allow consideration of the Th-P and $\mathrm{P}-\mathrm{P}$ distances as suitable for this purpose.

The thermal rocking of the corner-connected $\mathrm{ThO}_{6}$ and $\mathrm{PO}_{4}$ polyhedra is the probable cause of the moderate but continuous decrease of the Th-P distance in both $t$ and $c$ forms (Figure 9),

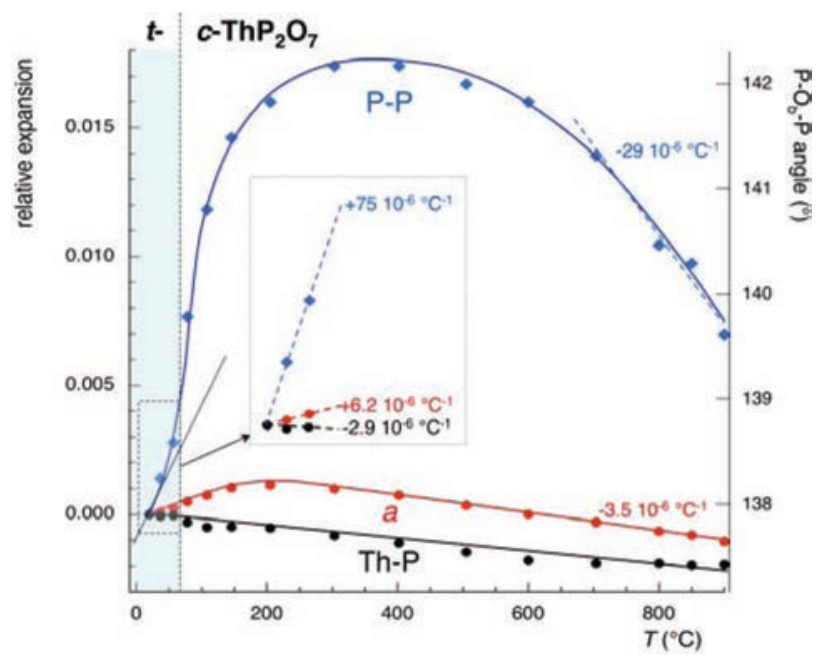

Figure 9. Relative thermal expansion curves of the cell edge $a$ and distances in corner-connected $\mathrm{P}-\mathrm{P}$ and $\mathrm{Th}-\mathrm{P}$ pairs. $\mathrm{P}-\mathrm{O}_{\mathrm{b}}-\mathrm{P}$ angle (right scale) is estimated from the $\mathrm{P}-\mathrm{P}$ distance. Shaded area corresponds to the $t$ form.

although the intensity of this contraction is limited by the expectedly faint thermal expansion of the Th-O bond. This contraction is also observed between -173 and $25{ }^{\circ} \mathrm{C}$ by synchrotron diffraction in the triclinic domain of $\mathrm{UP}_{2} \mathrm{O}_{7}$ (Table 2 ). On the other hand, the expansion of the covalent $\mathrm{P}-\mathrm{O}$ bonds can be considered as negligible, so the intense and nonmonotonous variations of the $\mathrm{P}-\mathrm{P}$ distance only result from the two modes of deformation of the $\mathrm{P}-\mathrm{O}_{\mathrm{b}}-\mathrm{P}$ linkage: the stretching at low temperature and tetrahedra rocking at high temperature, which rule the expansion of the whole cell by their intensity.

We can propose an explanation for the expansion in the lowtemperature domain on the basis of Birkedal's DFT model, in 
which the energy of an isolated staggered $\mathrm{P}_{2} \mathrm{O}_{7}$ unit was calculated as a function of the $\mathrm{P}-\mathrm{O}-\mathrm{P}$ angle. ${ }^{17}$ Figure 10 shows

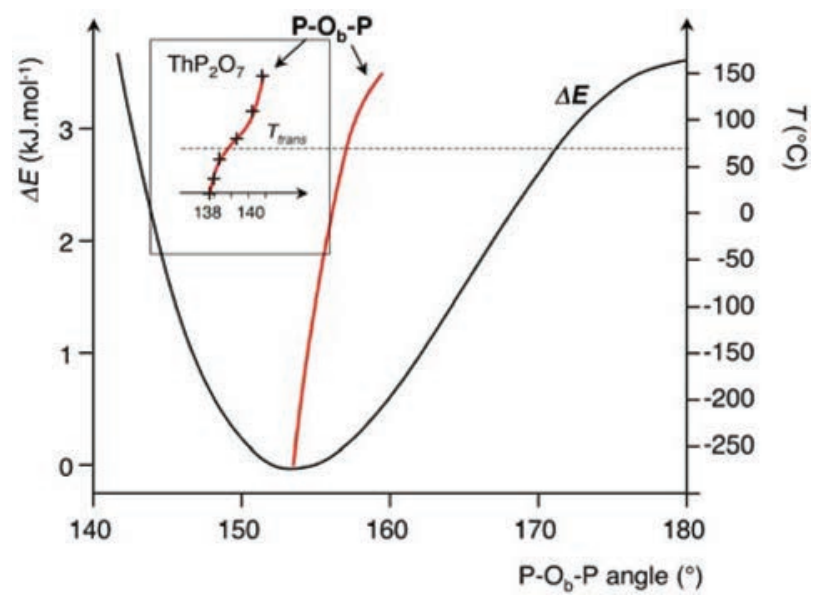

Figure 10. Energy $\Delta E$ of the isolated $\mathrm{P}_{2} \mathrm{O}_{7}$ unit as a function of the $\mathrm{P}-$ $\mathrm{O}_{\mathrm{b}}-\mathrm{P}$ angle, reproduced from Birkedal et al., ${ }^{17}$ and theoretical curve of the $\mathrm{P}-\mathrm{O}_{\mathrm{b}}-\mathrm{P}$ angle vs $T$ (right scale) explaining the thermal stretching of the $\mathrm{P}_{2} \mathrm{O}_{7}$ unit. Compare to the experimental curve for $\mathrm{ThP}_{2} \mathrm{O}_{7}$ (inset, shifted horizontal scale).

the anharmonic potential well, whose minimum corresponds to the equilibrium angle at $0 \mathrm{~K}$. The energy increases very rapidly when the angle decreases, whereas the slope is much lower at high angles. From this model we can infer that the average value of the $\mathrm{P}-\mathrm{O}_{\mathrm{b}}-\mathrm{P}$ angle increases with energy $\Delta E$. Thus, assuming $\Delta E=k T$, the $\mathrm{P}-\mathrm{O}_{\mathrm{b}}-\mathrm{P}$ linkage should expand on heating in the same way as the thermal expansion of a chemical bond $A-B$ arises from the asymmetry of the potential well of $E_{A-B}$ vs $d_{A-B}$. Note that the $\mathrm{P}-\mathrm{O}_{\mathrm{b}}-\mathrm{P}$ angle actually observed in $\mathrm{ThP}_{2} \mathrm{O}_{7}$ has a very similar behavior up to the transition point (Figure 10, inset).

Although some improvements could be performed by taking into account the interactions with the tetravalent cation and the torsion of the $\mathrm{P}_{2} \mathrm{O}_{7}$ unit, the DFT model offers an interesting correlation with the experimental measurements, suggesting that a precise analysis of the expansion mechanisms in the diphosphates could be obtained using this method.

The HT- $\mu$-Raman study of the $t-c$ phase transition was first conducted on $\mathrm{UP}_{2} \mathrm{O}_{7}$ samples. However, the interaction with the laser beam always led to a partial oxidation of $\mathrm{U}^{\mathrm{IV}}$ into $\mathrm{U}^{\mathrm{VI}}$, even under inert $\mathrm{Ar}$ atmosphere. In these conditions the appearance of the very intense $\nu_{1}$ vibration mode associated to the uranyl molecular ion ${ }^{53}$ precluded any reliable analysis of the spectrum. The study was then undertaken on $\mathrm{ThP}_{2} \mathrm{O}_{7}$ samples between room temperature and $280{ }^{\circ} \mathrm{C}$.

The spectrum recorded at room temperature fits well with that reported earlier ${ }^{29}$ and exhibits the vibration bands assigned to $\mathrm{P}-\mathrm{O}$ bonds and $\mathrm{P}-\mathrm{O}_{\mathrm{b}}-\mathrm{P}$ bridges. Particular attention was paid to the $\mathrm{P}-\mathrm{O}_{\mathrm{b}}-\mathrm{P} \nu_{\mathrm{s}}$ and $\nu_{\mathrm{as}}$ stretching bands since they could give precise information on this linkage. The symmetric elongation appears as a split band with components between 733 and $747 \mathrm{~cm}^{-1}$, in agreement with the triclinic model, whereas the faint $\nu_{\text {as }}$ vibration mode is observed around 970 $\mathrm{cm}^{-1}$ (Figure 11). According to Lazarev's relation, ${ }^{51}$ these values account for $\mathrm{P}-\mathrm{O}_{\mathrm{b}}-\mathrm{P}$ angles ranging between $137^{\circ}$ and $145^{\circ}$, in good agreement with the average value $\left(138^{\circ}\right)$ inferred from the Rietveld refinement. As expected, the $\nu_{\mathrm{s}}\left(\mathrm{P}-\mathrm{O}_{\mathrm{b}}-\mathrm{P}\right)$ vibration band reveals a progressive symmetrization on heating,

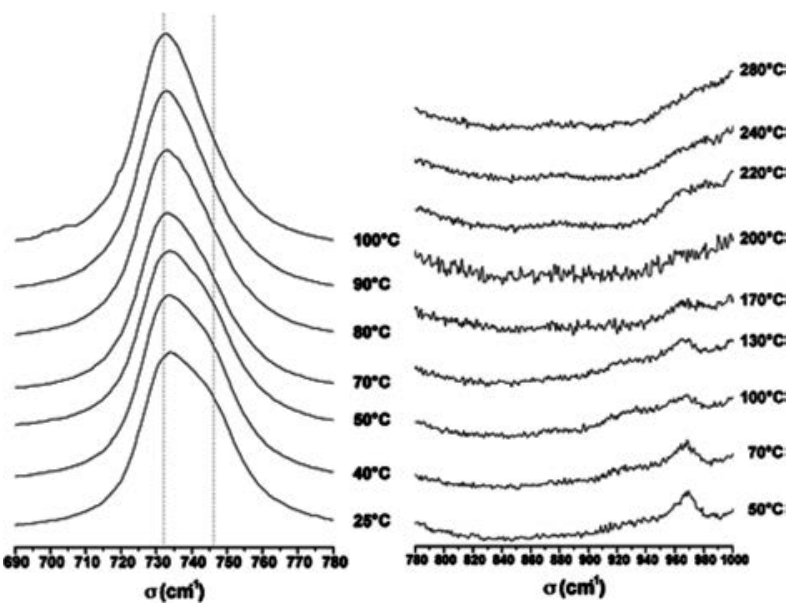

Figure 11. Variation of the $\nu_{\mathrm{s}}$ (left) and $\nu_{\text {as }}$ (right) $\left(\mathrm{P}-\mathrm{O}_{\mathrm{b}}-\mathrm{P}\right) \mu$ Raman vibration bands of $\mathrm{ThP}_{2} \mathrm{O}_{7}$ vs temperature.

yielding a single peak at $732 \mathrm{~cm}^{-1}$ between 80 and $90{ }^{\circ} \mathrm{C}$ to be correlated to the $t-c$ transition observed in the same range by XRD (Figure 9). Although it is commonly admitted that the $\nu_{\text {as }}$ vibration band should be extinct if the $\mathrm{P}_{2} \mathrm{O}_{7}$ unit becomes centrosymmetric, ${ }^{54}$ this mode can still be observed clearly at least up to $130^{\circ} \mathrm{C}$, that is, far above the transition point to $\mathrm{Pa}-$ 3. However, the band becomes very diffuse at higher temperatures. A possible explanation of this behavior can be proposed on the basis of the structural observations: even in the archetypal form, the $\mathrm{P}-\mathrm{O}_{\mathrm{b}}-\mathrm{P}$ linkage remains strongly bent, so the inversion center is relevant to a global disorder in the mean crystal cell, not to the real geometry of the diphosphate unit. Therefore, this mode remains active in the cubic form. The crossing of the inversion barrier, predicted to occur above $160{ }^{\circ} \mathrm{C}$ by DFT, conceivably results in intense variations of the angle. A wide dispersion of the phonon modes can be expected as well as a shortening of the coherence length, which both contribute to the broadening of the signal observed.

In the archetypal form, the annular distribution of $\mathrm{O}_{\mathrm{b}}$ around the inversion center allows a rocking of the corner-connected tetrahedra. Actually, this effect starts at the transition point, as shown by the inflection of the P-P expansion curve (Figure 9). At higher temperatures, the rocking becomes more intense and prevails over the stretching of the $\mathrm{P}-\mathrm{O}_{\mathrm{b}}-\mathrm{P}$ angle, resulting in a negative definite expansion of both the $\mathrm{P}-\mathrm{P}$ linkage and the cell edge. Thermal rocking, a common feature in cornerconnected arrays of polyhedra, is known as one of the most efficient ways to achieve zero or negative thermal expansion. ${ }^{19}$ As shown in Figure 9, the conflicting effects, each of them predominant in a domain of temperature, do not govern only the expansion of the $\mathrm{P}_{2} \mathrm{O}_{7}$ unit but also that of the cell. For this reason, the expansion plots of the five compounds (Figure 8) show roughly similar slopes at high temperature. However, in agreement with the previous mechanism, $A n^{\mathrm{IV}}$ cations smaller than $\mathrm{Th}^{\mathrm{IV}}$ form stronger $A n-\mathrm{O}$ bonds, more resistant to thermal disorder, so the temperatures of $t-c$ transition and inversion of expansion logically increase when the ionic radius of $A n^{\mathrm{IV}}$ decreases (Table 3).

Although negative thermal expansion is a very rare property among crystalline solids, several recent studies have pointed out the outstanding tendency of the phosphates of tetravalent actinides to contract over wide ranges of temperature. For example, whereas zirconium oxophosphate $\mathrm{Zr}_{2} \mathrm{O}\left(\mathrm{PO}_{4}\right)_{2}$ has been known since 1985 for its ultralow expansion $\left(+1.5 \times 10^{-6}\right.$ 
${ }^{\circ} \mathrm{C}^{-1}$ ), which makes it a remarkable refractory material, ${ }^{55,56}$ the actinide-substituted isotypes show a negative definite expansion: $-1.4 \times 10^{-6}{ }^{\circ} \mathrm{C}^{-1}$ for $\mathrm{U}_{2} \mathrm{O}\left(\mathrm{PO}_{4}\right)_{2}{ }^{57}$ and $-1.6 \times 10^{-6}{ }^{\circ} \mathrm{C}^{-1}$ for $\mathrm{Th}_{2} \mathrm{O}\left(\mathrm{PO}_{4}\right)_{2}{ }^{58}$ between 20 and $600{ }^{\circ} \mathrm{C}$. The structure, made of $\mathrm{MO}_{7}(\mathrm{M}=\mathrm{Zr}, \mathrm{U}, \mathrm{Th})$ and $\mathrm{PO}_{4}$ tetrahedra connected by edges and corners, is a priori unfavorable to a global rocking of the polyhedra, but the high ionic radii of the $A n^{\mathrm{IV}}$ cations allow independent transverse oscillations of the oxygen anions, responsible for the negative expansion. Likewise, $\beta$-thorium phosphate diphosphate $\left(\beta-\mathrm{Th}_{4}\left(\mathrm{PO}_{4}\right)_{4}\left(\mathrm{P}_{2} \mathrm{O}_{7}\right)\right)$ exhibits a nearzero expansion $\left(+1.9 \times 10^{-6}{ }^{\circ} \mathrm{C}^{-1}, 20-800{ }^{\circ} \mathrm{C}\right) .{ }^{59}$ Another strong point of the $A n^{\mathrm{IV}}$ phosphates regarding thermal expansion is the high valence of the actinide which makes the $A n-\mathrm{O}$ bond strong and therefore only faintly sensitive to temperature. Globally, the unequaled high-radius, high-valence combination makes this family an attractive field of research for low and negative expansion mechanisms.

\section{ASSOCIATED CONTENT}

\section{S Supporting Information}

Rietveld plot and CIF file of the $t-\mathrm{UP}_{2} \mathrm{O}_{7}$ structure solved from synchrotron diffraction and ${ }^{31} \mathrm{P}$ NMR shift in $\mathrm{UP}_{2} \mathrm{O}_{7}$ plotted against sample temperature. This material is available free of charge via the Internet at http://pubs.acs.org.

\section{AUTHOR INFORMATION}

\section{Corresponding Author}

*E-mail: gilles.wallez@upmc.fr.

\section{Notes}

The authors declare no competing financial interest.

\section{ACKNOWLEDGMENTS}

The authors would like to express their gratitude to D. Bouexière, G. Pagliosa, and R. Eloirdi for the collection of the X-ray data at ITU and A. Zappia for the DSC measurements. D. Bykov and K. P. acknowledge the European Commission for support given in the frame of the program "Training and Mobility of Researchers". D. Bykov acknowledges the DAAD for the financial support within the framework of the program "Forschungsstipendien für Doktoranden und Nachwuchswissenschaftler" and the ITU-JRC of the European Commission for providing facility for working with actinides.

\section{REFERENCES}

(1) Levi, G. R; Peyronel, G. Z. Kristallogr. Kristallgeom. Kristallphys. Kristallchem. 1935, 92, 190-209.

(2) Peyronel, G. Z. Kristallogr. 1936, 94, 311-312.

(3) Liebau, F.; Bissert, G.; Köppen, N. Z. Anorg. Allg. Chem. 1968, 359, 113-134.

(4) Burdese, A.; Lucco Borlera, M. Ric. Sci. 1960, 30, 1343-1345.

(5) Laud, K. R.; Hummel, F. A. J. Am. Ceram. Soc. 1971, 54, 296298.

(6) Shannon, R. D. Acta Crystallogr. 1976, A32, 751-767.

(7) Tillmans, E.; Gebert, W.; Baur, W. H. J. Solid State Chem. 1973, 7, 69-84.

(8) McMurdie, H.; Morris, M.; Evans, E; Paretzkin, B.; Wong-Ng, W.; Zhang, Y. Powder Diffr. 1987, 2, 41-52.

(9) Norberg, S. T.; Svensson, G.; Albertsson, J. Acta Crystallogr. 2001, C57, 225-227.

(10) Botto, I. L.; Baran, E. J. Z. Anorg. Allg. Chem. 1977, 430, 283288.

(11) Losilla, E. R.; Cabeza, A.; Bruque, S.; Aranda, M. A. G.; Sanz, J.; Iglesias, J. E.; Alonso, J. A. J. Solid State Chem. 2001, 156, 213-219.
(12) Fayon, F.; King, I. J.; Harris, R. K.; Gover, R. K. B.; Evans, J. S. O.; Massiot, D. Chem. Mater. 2003, 15, 2234-2239.

(13) White, K. M.; Lee, P. L.; Chupas, P. J.; Chapman, K. W.; Payzant, E. A.; Jupe, A. C.; Bassett, W. A.; Zha, C. S.; Wilkinson, A. P. Chem. Mater. 2008, 20, 3728-3734.

(14) Hagman, L. O.; Kierkegaard, P. Acta Chem. Scand. 1969, 23, 327-328.

(15) Chaunac, M. Bull. Soc. Chim. Fr. 1971, 424-429.

(16) Khosrovani, N.; Korthuis, V.; Sleight, A. W.; Vogt, T. Inorg. Chem. 1996, 35, 485-489.

(17) Birkedal, H.; Krogh Andersen, A. M.; Arakcheeva, A.; Chapuis, G.; Norby, P.; Pattison, P. Inorg. Chem. 2006, 45, 4346-4351.

(18) Stinton, G. W.; Hampson, M. R.; Evans, J. S. O. Inorg. Chem. 2006, 45, 4352-4358.

(19) Sleight, A. W. Inorg. Chem. 1998, 37, 2854-2860.

(20) Korthuis, V.; Khosrovani, N.; Sleight, A. W.; Roberts, N.; Dupree, R.; Warren, W. W. Chem. Mater. 1995, 7, 412-417.

(21) Brandel, V.; Dacheux, N.; Genet, M. J. Solid State Chem. 1996, 121, 467-472.

(22) Brandel, V.; Dacheux, N. J. Solid State Chem. 2004, 177, 47434754.

(23) Brandel, V.; Dacheux, N. J. Solid State Chem. 2004, 177, 47554767.

(24) Bamberger, C. E.; Haire, R. G.; Begun, G. M.; Hellwege, H. E. J. Less-Common Met. 1984, 102, 179-186.

(25) Boatner, L. A.; Beall, G. W.; Abraham, M. M.; Finch, C. B.; Huray, P.; Rappaz, M. In The Scientific Bases for Nuclear Waste Management; Northrup, C. J., Ed.; Plenum: New-York, 1980; Vol. 2, p 289.

(26) McCarthy, G. J.; White, W. B.; Pfoertsch, D. E. Mater. Res. Bull. 1978, 13, 1239-1245.

(27) Dacheux, N.; Clavier, N.; Robisson, A. C.; Terra, O.; Audubert, F.; Lartigue, J. E.; Guy, C. C. R. Acad. Sci. Paris 2004, 7, 371-375.

(28) Terra, O.; Dacheux, N.; Audubert, F.; Podor, R. J. Nucl. Mater. 2006, 352, 224-232.

(29) Clavier, N.; Wallez, G.; Dacheux, N.; Bregiroux, D.; Quarton, M.; Beaunier, P. J. Solid State Chem. 2008, 181, 3352-3356.

(30) Cabeza, A.; Aranda, M. A. G.; Cantero, F. M.; Lozano, D.; Martinez-Lara, M.; Bruque, S. J. Solid State Chem. 1996, 121, 181-189.

(31) Nectoux, F.; Tabuteau, A. Radiochem. Radioanal. Lett. 1981, 49, 43-48.

(32) Roof, R. LAUR-11619 1991, 3, 965.

(33) Giorgo, P. Z. Kristallogr. 1936, 94, 311-312.

(34) Douglass, R. M.; Staritzky, E. Anal. Chem. 1956, 28, 1211-1212.

(35) Burdese, A.; Borlera, M. L. Ann. Chim. 1963, 53, 333-343.

(36) Podor, R.; François, M.; Dacheux, N. J. Solid State Chem. 2003, 172, 66-72.

(37) Kirchner, H. P.; Merz, K. M.; Brown, W. R. J. Am. Ceram. Soc. 1963, 46, 137-141.

(38) Varga, T.; Wilkinson, A. P.; Haluska, M. S.; Payzant, A. J. Solid State Chem. 2005, 178, 3541-3546.

(39) Bamberger, C. E.; Haire, R. G.; Hellwege, H. E.; Begun, G. M. J. Less-Common Met. 1984, 97, 349-356.

(40) De, A. K.; Chowdhury, K. J. Chromatogr. 1974, 101, 63-72.

(41) Cordfunke, E. H. P.; Ouweltjes, W. J. Chem. Thermodyn. 1985, 17, 465-471.

(42) http://www.esrf.eu/UsersAndScience/Experiments/ StructMaterials/ID31/Technicaldescription.

(43) Bielecki, A.; Burum, D. P. J. Magn. Reson. A 1995, 116, 215220.

(44) van Gorkom, L. C. M.; Hook, J. M.; Logan, M. B.; Hanna, J. V.; Wasylishen, R. E. Magn. Reson. Chem. 1995, 33, 791-795.

(45) Bénard, P.; Louër, D.; Dacheux, N.; Brandel, V.; Genet, M. Chem. Mater. 1994, 6, 1049-1058.

(46) Rodriguez-Carvajal, J. FULLPROF.2k: Rietveld, profile matching and integrated intensity refinement of X-ray and neutron data, V 1.9c; Laboratoire Léon Brillouin: CEA, Saclay, France, 2001.

(47) Huang, C. H.; Knop, O.; Othen, D. A.; Woodham, F. W. D.; Howie, R. A. Can. J. Chem. 1975, 53, 79-91. 
(48) Rulmont, A.; Cahay, R.; Liègeois-Duyckaerts, M.; Tarte, P. Eur. J. Solid State Inorg. Chem. 1991, 28, 207-219.

(49) Pichot, E.; Emery, J.; Quarton, M.; Dacheux, N.; Brandel, V.; Genet, M. Mater. Res. Bull. 2001, 36, 1347-1359.

(50) Brese, N. E.; O'Keeffe, M. Acta Crystallogr. 1991, B47, 192-197.

(51) Lazarev, A. N. Vibrationnal Spectra and Structure of Silicates (English Translation); Consultants Bureau: New York, 1972.

(52) Taylor, D. Br. Ceram. Trans. J. 1988, 87, 39-45.

(53) Bartlett, J. R.; Cooney, R. P. J. Mol. Struct. 1989, 193, 295-300.

(54) Baran, E. J.; Mercader, R. C.; Massaferro, A.; Kremer, E. Spectrochim. Acta 2004, A60, 1001-1005.

(55) Yamai, I.; Oota, T. J. Am. Ceram. Soc. 1985, 68, 273-278.

(56) Wallez, G.; Launay, S.; Souron, J. P.; Quarton, M.; Suard, E. Chem. Mater. 2003, 15, 3793-3797.

(57) Wallez, G.; Launay, S.; Quarton, M.; Dacheux, N.; Soubeyroux, J. L. J. Solid State Chem. 2004, 177, 3575-3580.

(58) Wallez, G.; Clavier, N.; Dacheux, N.; Bregiroux, D. Mater. Res. Bull. 2011, 46, 1777-1780.

(59) Launay, S.; Wallez, G.; Quarton, M. Chem. Mater. 2001, 13, $2833-2837$. 